\title{
Religious Roots of Innovative Thinking
}

\author{
Dusan Kucera \\ Department of Managerial responsibility and ethics, University of Economics, Prague \\ Email: dusan.kucera@vse.cz
}

\begin{abstract}
The study is based on the identifying religious (spiritual) factors important for innovative thinking in entrepreneurship and management. The author uses the Weber's inspiring perspective analyzing the capitalism through the innovative religious concepts. It means that besides philosophical, sociological and psychological aspects there are very important and powerful religious roots which have a major impact on the emergence, development, and maintenance of the economic environment, business and management. These "self-transcendent" factors are described as fundamental roots used till today in the general spiritual concepts creating the needed frame and support of innovative thinking in entrepreneurial and managerial activities looking for any "new spirit of capitalism". Identified spiritual character of business potentials is distinguished by positive and negative spiritual (religious) factors based on world's religions. General religious (spiritual) factors are reflected on the background of basic selected religious systems Judaism, Christianity (Protestantism, Roman Catholicism and Eastern Orthodoxy) Islam, Hinduism, Buddhism and other Asian directions. The study culminates in the discovery of religiosity of the capitalism itself. All the abovementioned points are important contribution for better understanding of current multi-cultural and multi-religious growing trends.
\end{abstract}

Keywords: Spirituality, Religion, Innovation, Economy, Innovative Thinking

\section{Introduction}

The roots of innovative thinking can be identified in the fundamental philosophical and religionist systems which significantly influenced the gradual development of the innovative approach for centuries and have potential also to meet the challenges of today's business and management.

\section{Starting points}

\subsection{Concept of "religio"}

According to Cicero, the concept of religio derived from Latin relego - relegere $=$ to pick up again, take something into account, respect. The opposite meaning has negligare = neglect. According to Lactancius, it comes from Latin religo - religare = associate, rebind, e.g. human dependency on God; in the Bible known as conscience or manifestation of faith and piety or simply as religion. Immanuel Kant understood religion as recognition of moral law (categorical imperative or divine command). Friedrich Hegel wrote about an absolute spirit (absolute knowledge) with an emphasis on the whole. Friedrich Schleiermacher understood religion as awareness of infinity, contemplating the eternity. All these meanings have a great potential for innovative thinking.

\subsection{Spirit and innovative capitalism}

We find the basic spiritual understanding about business innovation in the Max Weber's concept of the spirit of capitalism on the basis of protestant ethics (Weber, 2004). We find the word spirit originally in Hebrew language (ruach = breath, wind, breeze). This «spiritually-charged word» occurs at the beginning of the universe (arché) as principle of all creation in the biblical Book of Genesis, but also in the first sentence of the Gospel of John. We can also say that the spirit is active at the beginning of any renewal process (lat. innovare). In the Old Testament, spirit conceived as «aspect of God's wisdom in the world». The fact that spirit is in the old Eastern mythologies and 
languages (Hebrew) in the feminine, it is also often associated with a "goddess». This introduction also marks the difference between the Hebrew ruach and Greek pneuma. Ruahis in ancient literature targeting with special idea, clearly focused, and typically characterized by their creativity and fertility. The Greek word pneuma, Latin spiritus, is neutral. This fact, unfortunately, in Greek and European philosophy «opens the possibility of harmful (value) neutrality and only abstract factuality which is used also in the current economic environment. The last note to the word spirit is the managerial formulation "entrepreneurial spirit", "entrepreneurial mindset" or in German - "unternehmerischer Geist", that is possible to update and deepen for innovative thinking. Spirituality, therefore, expresses the overlap of everyday life and their own existence, the emphasis on the meaning of its existence and acceptance of the mission toward the profession via innovation.

\section{Religious concept of the «invisible hand»}

Research of this popular concept has proved that the common mentioned «invisible hand of the market» cannot be impersonal or mindless because it is part of the current social and even spiritual framework of the economy. Swiss Economist Hans Christoph Binswanger from the University of St. Gallen writes in relation to it directly about «allesregelnde Vorsehungeinesweisen, machtigen und gutigenGottes", i.e. the "highest universal instance". Other metaphoric interpretation describes the invisible hand as a "divine intervention" in the society (Wieser-Rohrhuber, 2006).

\section{Anthropological basis of spiritual character of innovative thinking}

The anthropology reminds us on the humanity based on a combination of body - spirit - and soul (life). This spiritual function is usable as a source of each manifestation of human innovative thinking. This anthropological concept approaches the religious (vertical) concept of human vocation to be creative and innovative "image of God". We do not hit on any psychological effect (feeling, impression), nor on empirical influence of any idea in the society (the statistical and sociological majority of typical thinking and behavior). Human thinking, searching, receiving inspiration (in-spiritus), and the use of innovative capabilities in the context of values and meaning, is typical spiritual concept supported by some religions. In the economic environment, we follow the specifically human "search for meaning, unity, connectedness, transcendence and the highest potential" (Rican, 2007, p. 44).

It is remarkable how often economists, engineers, and technicians are talking about the inspiration and innovation without apparently realizing that they left the materialistic and purely scientific (empirical) basis. On the contrary they benefit in this area from religious sources. The German philosopher Karl Girgensohn described the typical spiritual experience of modern men as a search for inspiration and innovation, intention, and invention by three positions:

- Opening up the thinking that «overcomes our own border.»

- Confidence as the opening for answers to our internal questioning «in the imaginary and emotional forms.»

○ «The uplifting of myself for some higher goal - even e.g. loosing myself" in order to arrive a new target (Girgensohn-Gruhn, 1930).

\section{Concept of creation as basis for creativity and innovation}

According to the oldest religious ideas is the creation of man derived from the creation of the world. In addition, the world is designed by three factors: matter - energy - information (code of life). In the ancient world has been talking about the nature of the world as about special logos (code, gen of existence, art of thinking, nature) which contains the crucial channeling and targeting. Logos (word, idea) is the basis of the very beginning as well in the Jewish (Gen 1.1) as in Christian thought as the incorporated Word (John 1,1.14). For the European environment is very important the Jewish way of thinking which has strongly influenced the Christian history in Europe and US. This includes the following concepts:

- The existence of the universe, our planet, nature and humans because of the free decision of creator. For the entrepreneur and Manager it is the basic spiritual and meaningful basis of their creativity and innovation.

- Man was created with free will and was positioned into the environment of country with a specific mission and responsibility towards each other, nature, and people. This mission gives our innovative efforts permanent value and meaning. 
- For overcoming any obstacles, we got the spiritual energy (action of the Holy Spirit trough the divine word). No innovator has to work in a spiritual vacuum, because - as the Christian religion and finally articulates - the spirit is given to all, and forever.

- The institution of Sabbath provides human beings with the balanced rhythm of work and rest periods as an active experience for gaining more wisdom, spiritual energy that can be used for himself, family, and society (Kucera, 2012).

\subsection{Protestant roots of innovative thinking}

Weber understood the protestant spirit as the concept of an internal energy, intellectually focused and spiritually oriented personal power. The particular manifestation of protestant thinking we can consider in the emergence of modern capitalism:

- The liberation of individual from the power and from the economic catalyst role of papacy, which led to support of individualism (first as human position directly under the influence of God - homo coramdeo) and his own creativity.

- The liberation from Rome Empire led to the independence of the German first and other countries of Europe, and to their separate political and economic development.

- Philosophical and theological liberation of human beings led to the use of rationalism, humanism, spirituality, critical thinking of individuals, and responsible human activity.

- The liberation of man in economic activity led (first in the Lutheran Germany) to the freer development of crafts, cities, business activities, construction of modernism, and, of course, to the emphasis on personal and professional development.

- The interpretations of the New Testament teachings about God's pardon for every individual has become the strongest and deepest topic making free for the daily systematic work and new creativity.

Other spiritual potentials, supplemented later by Calvinism we can summarize as:

- Active interest for the work efficiency as a manifestation of spiritual channeling.

- Active spiritual challenge to the calculated orientation and rational strategy.

- The concept of profit as a sign confirming the spiritual (divine) calling for the creation of values.

- Inclination for saving (opposite of indebtedness).

- Spiritual energy to risk and deal with crisis.

\section{Postmodern calling after ,new spirit of capitalism".}

Many scientists claim that the abandoning of initial spirit of capitalism causes the decadence of Europe today. Very concrete contradictions describe the situations when the businessmen consider profits as private, but with the common cost try to burden the state. Observing that the original «spirit of capitalism» dies, we meet the calls for a «new spirit of capitalism» with the original protestant characters of entrepreneurship (Boltanski - Chiapello, 2003) which would on this way find a new source for the development of stagnating Western companies.

\subsection{Spiritual intelligence and its application in the innovative thinking}

Some scientists (Zohar - Marschall, 2003) suggest using the phenomenon of spiritual intelligence as a truly higher (vertical) level of innovative mindset. We know that the method of IQ (intelligence quotient) follows the logical capabilities of rational procedures, the emotional intelligence (EI) is working in the sphere of inner empathy and motivation, but the spiritual intelligence dares to aim even higher goals:

- The ability of mental flexibility - it means to think actively and spontaneously with a willingness to deal with new ideas regarding to customer needs.

- High degree of self-confidence as a spiritual orientation, which the entrepreneur and manager has to learn and use.

- The ability to face problems and difficulties.

- Be ready to be inspired by values and new visions.

- The ability of a holistic thinking to see things in the context of interconnections.

- The effort to ask mainly «why» or «what if», and search for answers to the deepest questions (not just to a pragmatic and functional questions such as «how», «who», «where» and «when»). 
○ Get the internal personal and moral - visionary independence.

In comparison between purely functional and holistic assessment, we follow a series of contradictions, e.g.:

Table 1: Value contradictions

\begin{tabular}{|l|l|}
\hline Functional perspective & Holistic/ethical perspective \\
\hline Functionality & Responsibility, Accountability \\
\hline Rationality & Wisdom, balance thinking \\
\hline Paradigm of reduction & Plurality \\
\hline Pride & Humility \\
\hline Past, presence & Future \\
\hline Short term orientation & Long term orientation \\
\hline Variability & Stability and continuity \\
\hline Rules & Vision and future orientation \\
\hline Purpose & Sense \\
\hline Randomness & Systematical order \\
\hline Effect & Value added \\
\hline
\end{tabular}

Source: Schütz, 1999, p. 69 (own adaptation)

\subsection{Innovative aspects of Jewish spirituality}

When Max Weber wrote about the "spirit of capitalism" based on Protestant ethics, he knew, of course, also the primary historically role of Judaism in the birth and development of European culture in general and the development of entrepreneurship in particular:

- The concept of work as a virtue against the current complaints about work as a «punishment» or annoying obligations.

- The emphasis on private property as an expression of God's calling, blessings and individual freedom (creative partnership with God).

- The emphasis of the Hebrew bible on the integrity, freedom and independence of the individual in his thinking.

On the Jewish background for entrepreneurship is based also the Christianity with the common fundaments for innovative thinking (Kucera, 2012):

- The world has its noble origin and meaning. Therefore, also man, his life and work has special value, meaning, and purpose.

- The world is created in perfection and certain order. Man is set in the frame of world order on which he can rely and which he can discover and deepen.

- The world is in its diversity and universality declared as «good», and is designed for man's life and his creative and innovative work.

\subsection{Catholic roots of innovative thinking}

In the literature we find special contribution from some scholastics of the 16 and 17 century. They wrote surprisingly about the free market theory at that time. Thomas Aquinas defined the natural right as a «share of the eternal law in rational beings" (participatiolegisaeternae in rationalicreatura). Alejandro Chafuen explains that Aquinas refers to the eternal law, «God's plan» which is «the whole creation to its ultimate goal.»For the practical thomistic thinking is important the foundation of «rational use of human understanding». (Chafuen, 2011, p. 15). For our context with innovation is interesting the scholastic Ludwig von Mises who lists the three main benefits of the Catholic faith for management:

- belief in the existence of the natural order,

- the importance of human ration and imagination as the means of understanding an using of natural order for special goals

- Methods for the ethical assessment and value consequences. 
Francisco Pierre de Jean Olivi (1248-1298) in his tractate about the «fair price» wrote, that it is not possible to calculate price from the «objective factors» (e.g. only direction or workload). He wanted to derive the fair price from the relationship between the seller (entrepreneur, trader) and the purchaser (the customer). Among the Spanish Jesuits it was then cardinal Juan de Lugo (1583-1660) and Luis de Molina (1535-1600). They represents the understanding of the «grace of God» as donation, which supports the free individual thinking. In the Molin's writings «De jure etIustitia» he stands for a»fair price» which may be regarded as the manifestation of «God's grace» for all free participants working «without any tricks, monopoly and other slickness or privileges.» (Jezek, 2009, p. 10).

\subsection{Orthodox roots of innovative thinking}

No special study is available on this topic. However, we can rely on certain sources that can be found questionable, sources that are in tension with the Western concept of innovation necessary for entrepreneurship and management, if not contrary. This paragraph does not intend to deny the existence of any manifestation of individual business or managerial activities in the Great Russian country. Yet when looking for any Russian spiritual resources, we must recognize their traditional and long-term difference from Western thinking and specifically from Protestantism. We could expect a new hope, naturally, during the last twenty years; however, the available analyses are revealing rather the so-called "pseudomorphosis" of the Russian society (Putna, 2015).

The basic characters of Russian spirituality are bound to orthodoxy, which originally comes from the Catholic thinking and retains many of the mythical imaginations. They are the ideas of the great Russia («the heavenly Russia»), which is to be defended (against enemies) and fought for (sacrifice the lives). Orthodoxy draws its original authority historically from the concept of Moscow as the «third Rome» (after the fall of the first Rome and Constantinople as a second Rome). The Russian mentality is based on nationalism supported by orthodox religiosity. We see the consequences in the national mission based more on common obligations to the nation, than on common rights for personal development and effective employability or entrepreneurship. We find the explanation in the Byzantine, Mongolian and Soviet legacy (Kostka, 2015). The strong national (up to nationalist) feeling, however, is connected with the Orthodox Church, its theology and faith in the national ruler (formerly the czar, patriarchs and the princes). These dominant ideas are related with a weaker consideration for the private property, democracy and free entrepreneurship till today. For the classic business, the strong, secured and free thinking individuals are missing here, as well as the civic institutions, independent ownership rights (law) and civil society (democracy instead of a strong central power). This is the basic standard in contrary for e.g. Protestantism - the free spiritual and inspirational relationship of individuals "coramdeo". It is not without significance that the Russian word "vladét" (to rule) means also "to possess". The precondition of personal responsibility (lat. respondeo - answer for higher calling) is missing. From this assumption, certain Russian fatalism of individuals against the rulers was also born, in contrary to the free selfconfident individuals ready to change the conditions in society. In this context, the Russian spirituality is supporting the oligarchy more than the small entrepreneurs. The last considerations could deal with the structure of the Russian economy based more on raw material than on processing industry.

\subsection{Muslim roots of innovative thinking}

A large part of contemporary business world are the Muslim countries whose thinking (Islam) has a lot in common with the biblical religion:

- As monotheistic thinking, it believes in one God, the creator, the universal ruler, and keeper of the world which gives our world a certain order. In this reliable order, a Muslim can live and work free (Kropacek, 1994).

- The Muslim-oriented entrepreneur believes that his faith is proven in the way of his life and work; he believes in the sense of «good deeds» which can be (innovatively) developed.

○ Good deeds are «added up» and are eventually evaluated in the last «day of judgment». It is a crucial defense against laziness or spiritual passivity.

$\circ$ The awareness of the permanent presence of Allah in the life of a Muslim frees him from fear and adds his courage for specific decisions and actions.

- The relationship between a Muslim and Allah is direct without intermediaries (in contrary to the Roman Catholic Church with its number of saints and advocates); this represents a deep and powerful source of his spiritual energy and orientation for a Muslim.

$\circ$ The supporting rhythm of work and rest periods (Ramadan). 
- A prayer, as a means for innovative thinking, providing spiritual rest, cleansing, forgiveness, mission, source of motivation, and value framework.

- Success as a sign of God's favor - similar to Calvinism.

\subsection{Hindu roots of innovative thinking}

Hindu culture and religion offers a rather relaxing and meditative environment (Küng, 2006):

- It puts the individual into the world order with which one has to get to a harmonious relationship.

- Benefit from a craving and ownership at any price.

- Teaches the promotion of good objectives by using of non-violence.

For Western managers (full of stress and depression) the Hindu environment is a frequent destination for their trips; it enables them to find their lost inner balance again, to find peace and a new concept of values, which include:

- Spiritual openness to new inspiration from the infinity of the universe.

○ Realistic point of solution, which a Hindu seeks «beyond his reason».

$\circ$ The use of the concept of divinity in the soul of every human being.

\subsection{Buddhist roots of innovative thinking}

Weber regarded Buddhism as a «mystical concentration of internal enlightenment». It manifests itself as the contemplation of spiritual focus on meditation, which ,relieves the spirit of man from longing for the world - and from any connection with some pure secular interests" (Weber, 1977, s. 274).

\subsection{Confucian roots of innovative thinking}

In Confucianism, we find very beneficial factors giving emphasis on the practical values of life, ethics, compliance with the universe and always present accent on the «wisdom». The Eastern concept of wisdom is completely different from the Western concept of «cleverness» and pure information. In Confucian wisdom is important the spiritual understanding of the whole world finding its meaning and personal position in it. With this finding is related the valuation of entrepreneurial activity in the world order (Küng, 2006).

\subsection{Taoist roots of innovative thinking}

In Taoism, we find a very remarkable innovative initiative for a holistic conception of man and of the world. Although this ancient Chinese philosophy reflects all the opposites in the world, in the same time is looking in the global dynamics for the holistic harmony. This shows the known diagram:

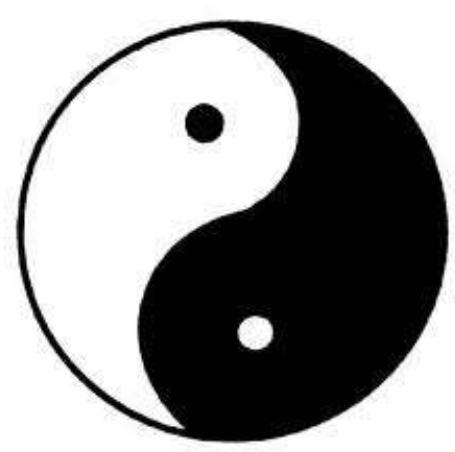

Figure 1: Symbol Yin - Yang.

Source: http://symboly.xrs.cz/jin-jang/

The modern entrepreneurs and managers know some accents, e.g. in the Chinese medicine. Generally, we find in the Taoism following aspects:

- The concept of life and work as the «right path».

○ The use of a combination of work with value-oriented «spirit» by using holistic, dialectic or dynamic duality (Fang-Faureb, 2011) instead of static and bipolar world.

○ The traditional symbol works with the phenomenon of the universality and with two opposing energies of the universe. Very useful is this model for problem solving methods:

- Yin: the female part of the world: moon, night, weakness, softness. 
- Yang: the men's site of the world: sun, day, strength, clarity, hardness.

- A black dot in the white field and the white dot in the black field are symbolizing the parts of opposition power in the contrary field.

- The curve inside the circle indicates that opposites are not strict and absolute, but that sometimes are overlapping.

- The whole principle of the paradox is illustrated by duality, unity in diversity and the dynamic process of change within a single unit.

\subsection{Shinto roots of innovative thinking}

«Šinto» means «path of the gods». In this ancient and yet still alive religion in Japan we are finding a huge respect for rituals of devotion to country, group, family, and company. From the Shinto originated are well known the accents for excellence and quality of type «kaizen». Strong elements of Shinto are known even from the innovative war strategy (Küng, 2006).

\section{Holistic understanding of innovative scientific thinking}

On the basis of Descartes and his ,turnover to the subject» was initiated the historical division of originally single science dealing with the whole universe (universitas). Distribution of «res cogitans» and «res extensa» was transferred to the division of exact and empirically measurable natural science and moral philosophy. Here we can refer to the distribution of German division of the most Colleges in the «Naturwissenschaften» - natural sciences, and «Geisteswissenchaften» - spiritual sciences. This concept for innovation helps to keep track with the concept of science as one unit (Anzenbacher, 2004). For example: the economics is not universal science but only the part of social sciences.

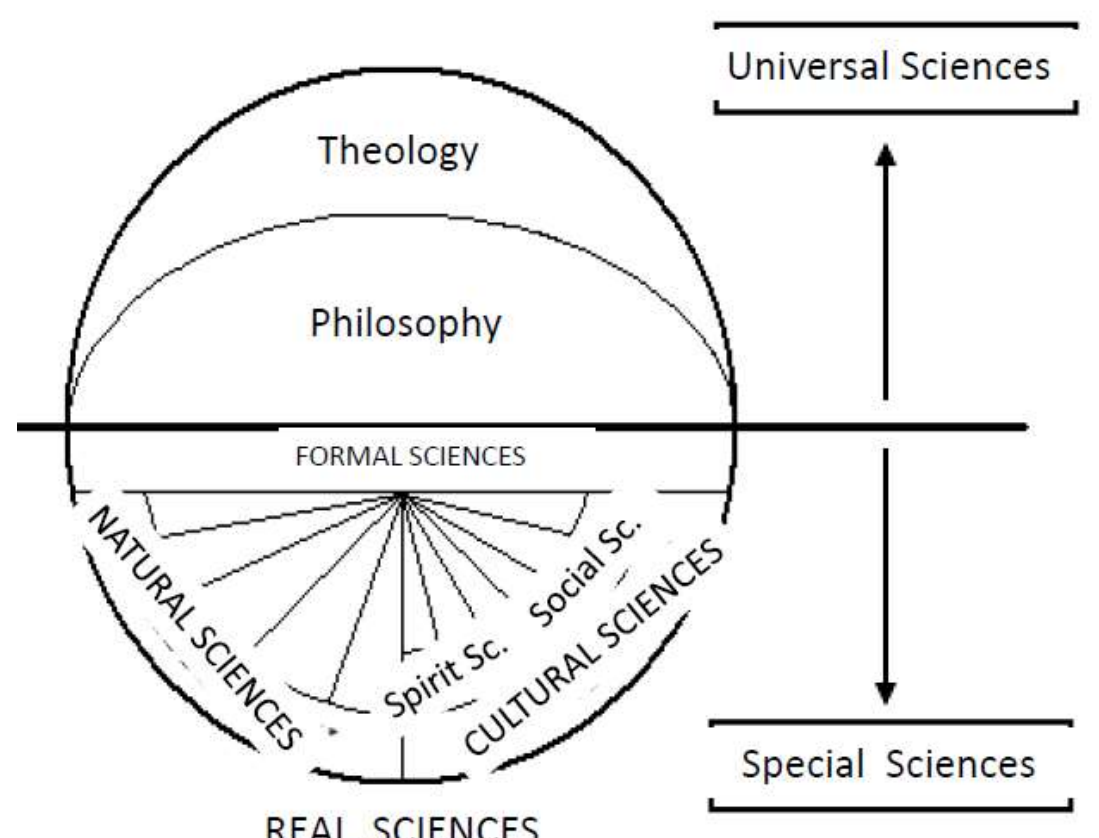

Figure 2: A comprehensive conception of the scientific environment. Source: ANZENBACHER, 2004: Úvod do filozofie, p. 35.

\section{Practical understanding of complex innovative environment}

Munich Professor Friedrich Hanssmann concluded that all the activities of human society can hardly be divide into the separate system areas such as economics and politics as separated thinking domains. On the contrary, man and his environment builds a unit which includes all other elements (Hanssmann, 2010). His concept is based on the methodology of the Austrian scientist Johann Millendorfer who is known as the researcher with spiritual visions about the future with a few propositions: 
- Economic success cannot be attributed only to purely economic factors.

- The life context of man is based on a network of relations between people - things - and their purposes.

- On the introduced framework basis (see fig. 29) he shows his understanding for the prosperous development of the future economy and society (the so-called values of the future). They are also available for practice.

The specific relationships are displayed between following subsystems:

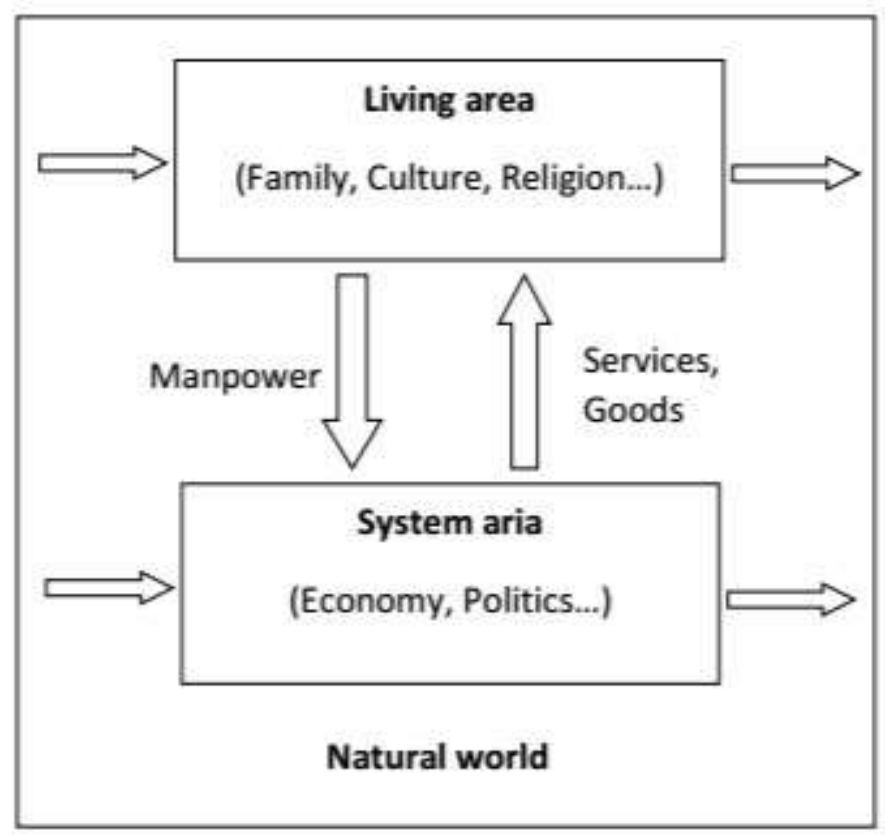

Figure 3: Simple System Model

Source: HANSSMANN, 2010, p. 6.

\section{Religious features of capitalism itself}

Walter Benjamin has written that capitalism carries significant religious features, structures and cultic effects (Kreutzer, 2000). Harvey Cox identifies "market” without scruples as a "deity» (Cox, 1999). Also, one Czech author speaks about "quasi-theological or quasi-religious structure" of capitalism (Chalupníček, 2007, p. 84). The economists are trying to introduce their concept of the world as a whole, differently from the hypothesis of God according to the concept of the "invisible hand". The last remark belongs to the very modern and post-modern manifestation of capitalism as a religious phenomenon with concrete religious forms:

○ Universe - pantheisms of money, devotion to "the dollar" (Cox, 1999). The world of experiences and enjoyment, happiness of consuming is declared as "divine" or in contrary as "devil".

- Temples - company buildings, skyscrapers of banks (Koch, 2000, p. 38).

- Priests - capitalists and famous managers, owners of global companies.

- Bible - management literature on success of business.

- Rituals - ecclesiological morphology of company celebrations, certificates, symbols, orders, hierarchy, equipment and location of director office.

- Saints - successful managers "stars of business heaven", adoring their pictures, statues, quotations, products, brands, personal "stars aspiring the heaven".

- Sacrifices - hard way how to get rich, big property, risk, interests.

- Credo - the phenomena of credibility, credits, credit card (credo = believe, trust) vs. debit (orig. in the Bible "sin").

- Faith - believing in the endless economic growth and future development, overcoming all the obstacles, etc. Dollar title: ,In God we trust”.

- Eternity - Accents on sustainability and permanent growth of economy

- Justification -entrepreneurial success asauthorization and permission to be called e.g. as the part of "blessed America". 
○ God - double role of money (capital, bonds) as an absolute instrument and final goal of capitalistic entrepreneurship, the almost absolute - omnipotent power of money. "The money is the God of our time" (Simmel, 2013, p. 18-20) or we can also speak about the "pantheism of money" (Hagen - Welker, 2014, p. 96). On the other hand we can speak about "mammon" and "idolatry".

The absolutism of money (capitalism), as a form of religion which we are to decide for, is finally given and even more complicated in the value context outlined by Mathew in the text of The New Testament: "No one can serve two masters. Either you will hate the one and love the other, or you will be devoted to the one and despise the other. You cannot serve both - God and money" (Mat. 6, 24).

\section{Conclusion}

The study identifies general spiritual or concrete historical religious factors which have an immense innovative potential in entrepreneurship and management. We conclude that that there are spiritual factors transcending the known philosophical, sociological and psychological aspects of the innovative thinking. The study indicates articulated connections between religious roots and their significant impacts on the emergence, development and maintenance of the economic environment, business and management. It is seldom that this approach is chosen. Especially in Eastern Europe in the post-communist countries is this topic absolute absent. Even the rediscovery of spiritual character in the capitalism itself is in the post-communist market economies a great surprise and a parallel and unknown phenomenon. For example in a country which declares itself as pure industrial, scientific, modern economic and even "atheistic" country. Religious factors described in the innovative thinking can be effectively considered and applied in the fields concerned with entrepreneurship and management. This topic is increasingly important due to the development of current multi-cultural and multi-religious society.

\section{References}

- Anzenbacher, Arno. (2004): Úvod do filozofie. (Introduction tot hephuilosophy) 2. edtion, Praha, Portal, 2004, 384 p.,ISBN978-80-7367-727-5.

- Boltanski, Luc. - Chiapello, Eve. (2003): Der neue Geist des Kapitalismus. (The new Spirit of Capitalism). Édiciondescours, Konstanz: UVK Verlag 2003, 736 p., ISBN 3-89669-991-1.

- Fang, Tony - Faureb, Guy, Olivier. (2011): Chinese communication characteristics: A Yin Yang perspective. International Journal of Intercultural Relations, Volume 35, Issue 3, May 2011, p. 320-333.

- Girgensohn, Karl - Gruehn, Werner. (1930): Der seelischeAufbau des religiösenErlebens: einereligionspsychologischeUntersuchung auf experimentellerGrundlage (The mental structure of religious experience: a religious and psychologic study on experimental basis). 2. Editon, Gütersloh, Bertelsmann, 1930.

- Hanssmann, Friedrich. (2010): Christliche Werte in Wirtschaft und Gesellschaft (Christian values in businessandsociety). 1. Edition, Berlin, LIT Verlag, 171 p. ISBN 978-3-643-10489-2.

- Hagen, Jürgen von - Welker, Michael. (2014): Money as God? The monetization of the market and the impact on religion, politics, law and ethics. 1. Edition, Cambridge University Press, 101 p. ISBN 978-1-107-04300-8.

- Chafuen, A. Alejandro. (2011): Vira a Svoboda (Faith and Freedom). 1. Edition, Praha, WoltersCluwer, 212 p., ISBN 978-80-7357-656-1.

- Ježek, Tomáš. (2009): Spravedlivácena a španělštíjezuité (Fair price and Spanish Jesuits). Texty Nr. 1, 11/2009, p. 9-13, Christian College, Praha 2009, ISSN 1804-1655.

- Koch, Kurt. (2000): Konfrontacenebo dialog? Palčivéotázkydneška a křestanskávíra (Confrontation or dialogue? The burning issues of today and the Christian faith). 1. edition, Praha, Vyšehrad, 288 s., ISBN 807021-263-2.

- Kropáček, Luboš. (1994): Islámaekonomie (Islam and Economics).Teologickétexty, 1994/2, p. 59-61.ISSN 0862-6944.

- Küng, Hans. (2006): Po stopáchsvětovýchnáboženství (Following the footsteps of the world's religions). 1. edition, Brno, Centrum pro studiumdemokracie a kultury, 306 p., ISBN 80-7325-059-4.

- Owagner, G.; Hessinger, P. (2008): Ein neuer Geist des Kapitalismus? Paradoxien und Ambivalenzen der Netzwerkokonomie (A new spirit of capitalism? Paradoxes and ambivalences of Network Economics). Wiesbaden, 1. edition, VS Verlag fur Sozialwissenschaften, 342 p., ISBN 978-3-531-15315-5. 
- $\quad$ Ríčan, Pavel (2006): Spiritualitajakoklič k osobnosti a lidskýmvztahům (Spiritutality as a key to personality and human relations). Praha,Československápsychologie, 50, 2, p., 119-137.

- Schüz, Mathias. (1999): Werte - Risiko - Verantwortung (Values - Risk - Responsibility), 1. Editon, München, Gerling Akademie 1999, 213 p., ISBN 3-932425-20-0.

- Simmel, Georg. (2013): Philosophie des Geldes (Philosophyofmoney). Hofenberg, ISBN-10: 3843025010

- Weber, Max. (2004): Die protestantische Ethik und der Geist des Kapitalismus (The protestantethicandthespiritofcapitalism). 2. edition, C. H. Beck, München, 2004. 432 p., ISBN 978-3-40660200-9.

- Zohar, Danah\& Marschall, Ian.(2003): Spirituální intelligence (The spiritual intelligence), 1. edition, Praha, Mladáfronta, 288 p., ISBN 80-204-1030-9.

- Kreutzer, Ansgar. (2000): Ich glaube, es ist gottgewollt, daß wir arbeiten. ZurSinnschöpfungdurchErwerbsarbeit (I think it is willed by God that we are working. Tothe sense ofcreationthroughemployment). FagsF 25. 7/2000. Nell-Breuning-Institut Frankfurt für Wirtschafts- und Gesellschaftsethik, der Philosophisch-Theologischen Hochschule Sankt Georgen, 32 Seiten, Retrieved 28 March 2013 fromhttp://www.sankt-georgen.de/nbi/fileadmin/redakteure/Dokumente/2000/FagsF-25.pdf

- Kučera, Dušan. (2012): Myšlenkovépotenciályšabatu v hospodářsképospolitosti (The spiritual potentials of Sabbath in the economic community).Praha, E-Logos, Electronic journal for philosophy, 8/2012, University of Economics Prague, 16 p., ISSN 1211-0442. Retrieved 20 April 2013 from: http://elogos.vse.cz/index.php?article $=322$

- Chalupníček, Pavel. (2007): Hodnotovésoudy v ekonomii. Ruznépohledynahranicimezi „pozitivním” a „normativním” (Value judgements in economics. Various views on the border between "positive» and «normative”). University of Economics, Prague, workshop 14 March 2007. Retrieved 3 June 2014 from http://nf.vse.cz/doktorske-studium/workshopy/workshopy-2007/

- Wieser, Renate - Rohrhuber, Julian. (2006): The Invisible Hand, in: Goriunova, Readme 100, Temporary Software Art Factory, Norderstedt". Retrieved 5 November 214 from: http://wertlos.org/ rohrhuber/articles/Rohrhuber_Wieser_invisible_hand.pdf 